\title{
ДОСЛІДЖЕННЯ АНТОЦІАНІВ ЛУШПИННЯ ЦИБУЛІ РІПЧАСТОЇ
}

\begin{abstract}
Вступ. Актуальним завданням сьогодення є вивчення хімічного складу і біологічної активності відходів рослинництва. До рослин, що утворюють як первинні, так і вторинні відходи, належить цибуля ріпчаста - Allium cepa L., родини Alliaceae. Первинні відходи цибулі ріпчастої (лушпиння) утворюються безпосередньо після збору врожаю, вторинні - при переробці харчовою промисловістю (ДСТУ-3234-95 - Цибуля ріпчаста свіжа).

Мета дослідження - вивчити якісний склад та кількісний вміст антоціанів у лушпинні цибулі ріпчастої сортів "Ред барон" $і$ “Марс".

Методи дослідження. Наявність даної групи сполук у лушпинні цибулі ріпчастої обох сортів підтверджували якісними реакціями з лугом та плюмбумом ацетатом основним і тонкошаровою хроматографрією. Для кількісного визначення суми антоціанів використовували модифрікований спектрофотометричний метод, наведений у 2-му виданні Державної Фармакопеї України, зокрема в монографрії “Чорниці плоди свіжі".

Результати й обговорення. У результаті хроматографрічного дослідження в лушпинні цибулі ріпчастої обох сортів, порівняно з достовірними зразками антоціанів, було виявлено мальвідин-3-О-глікозид, мальвідин-3,5-диглікозид, дельфрінідин-3-О-глікозид, ціанідин-3-О-глікозид, ціанідин-3,5-диглікозид. Методом прямої спектрофротометрії в лушпинні цибулі ріпчастої сортів "Ред барон" “ "Марс" встановлено кількісний вміст антоціанів - 0,097 \% 0,003 та 0,320 \% 0,002 відповідно.

Висновки. Методом тонкошарової хроматографрії, порівняно з достовірними зразками, в лушпинні цибулі ріпчастої сортів "Ред барон" та "Марс" ідентифріковано 5 антоціанових глікозидів. Підібрано оптимальні умови для максимального вилучення антоціанів із лушпиння цибулі ріпчастої. Визначено кількісний вміст антоціанів у лушпинні цибулі ріпчастої сортів "Ред барон" та "Марс".
\end{abstract}

КЛЮЧОВІ СЛОВА: антоціани; цибуля ріпчаста; лушпиння.

ВСТУП. Вплив шкідливих фракторів навколишнього середовища, незбалансованість сучасного харчування (дефріцит харчових волокон, білка, вітамінів, мікроелементів) загострюють потребу в спеціальних продуктах харчування, яку частково можна задовольнити шляхом раціонального використання вторинної харчової сировини. Екологічне вдосконалення виробництва передбачає економію споживаних ресурсів та зменшення маси відходів [1].

У 2010 р. загальний обсяг вирощених у рослинництві культур (зернові, технічні, кормові та овочеві) становив 59 млн т. У рослинництві й промисловості з переробки продукції рослинництва щорічно утворюється близько 80 млн т відходів, 3 них 60 млн т - це первинні відходи, що утворюються після збору врожаю, і 20 млн т - це вторинні відходи, які виникають у результаті (с) В. Ю. Кузнєцова, В. С. Кисличенко, Н. А. Сущук, 2018. технологічних процесів перетворення цільової сировини в харчову продукцію [2].

Тому актуальним завданням сьогодення $€$ вивчення хімічного складу і біологічної активності відходів рослинництва. До рослин, що утворюють як первинні, так і вторинні відходи, належить цибуля ріпчаста - Allium сера L., родини Alliaceae. Первинні відходи цибулі ріпчастої (лушпиння) утворюються безпосередньо після збору врожаю, вторинні - при переробці харчовою промисловістю (ДСТУ-3234-95 - Цибуля ріпчаста свіжа).

Цибуля ріпчаста (Allium cepa L.) - дво- або багаторічна рослина. Цибулини кулясто-плескаті або кулясто-довгасті (залежить від сорту й умов середовища), з плівчастими, суцільними жовтими, червонуватими, фріолетовими або білими зовнішніми лусками і м'ясистими внутрішніми $[3,4]$. 
Крім широкого використання цибулі ріпчастої в харчовій промисловості, її цибулини здавна застосовують у народній медицині при дерматологічних, урологічних та гастроентерологічних захворюваннях. До того ж, біологічно активні речовини цибулі входять до складу комплексних препаратів "Контрактубекс" ("Merz Pharma GmbH \& Cо. KgаA", Німеччина), "Уронефрон” (ПАТ “Фармак", Україна), “Фітоекстракт рідкий” (ПАТ “Фармак”, Україна), “Фітоекстракт густий” (ПАТ “Фармак”, Україна), “Фітолізин Плюс" (ПАТ "Фармак", Україна), "Сухий екстракт з 9 рослин" ("Alban Muller International”, Франція), “Фітолізин" (ТОВ “Гербаполь”, Польща) [5].

Цибулини Allium сера L. містять комплекс біологічно активних речовин, серед яких вуглеводи, ефрірна олія, френольні сполуки, азотисті речовини, органічні кислоти та ін. У забарвлених зовнішніх лусках Allium cepa L. $€$ значна кількість (до 8 \%) фрлавоноїдних сполук (антоціанів і фрлавонолів). Антоціани виконують фрункцію рослинних пігментів завдяки особливій структурі їх молекул, що забезпечує їх поведінку як селективного приймача випромінювання окремих ділянок спектра сонячного світла. Усе різноманіття відтінків антоціанів залежить від будови, положення та кількості функціональних груп. Якісний склад антоціанів, як правило, є специфрічним для кожного виду рослини. Також антоціани захищають внутрішні шари цибулини від проникнення деяких мікроорганізмів [3, 4].

На даний момент антоціани широко використовують у всьому світі як харчові барвники, які не тільки забезпечують різноманітність кольорів та відтінків, а ще й проявляють низку видів біологічної активності: знижують рівень холестерину, попереджують утворення тромбів, підвищують еластичність судин, прискорюють загоєння ран тощо [6].

Лушпиння цибулі ріпчастої червоних сортів $€$ доволі перспективним джерелом з достатньою сировинною базою для одержання екстрактів, багатих на антоціани [3].

Мета дослідження - вивчити якісний склад та кількісний вміст антоціанів у лушпинні цибулі ріпчастої сортів "Ред барон" i “Марс".

МЕТОДИ ДОСЛІДЖЕННЯ. Наявність даної групи сполук у лушпинні цибулі ріпчастої обох сортів підтверджували якісними реакціями 3 лугом та плюмбумом ацетатом основним і тонкошаровою хроматографрією.

Для кількісного визначення суми антоціанів використовували модифрікований спектрофотометричний метод, наведений у 2-му виданні Державної Фармакопеї України, зокрема в монографрії “Чорниці плоди свіжі”. Він оснований на тому, що антоціани мають абсорбційний максимум у ділянці 510-550 нм, досить віддаленій від спектрів поглинання інших френольних сполук, які містяться в лушпинні цибулі ріпчастої, що не може впливати на кількісне визначення антоціанів [6-9].

Для приготування випробовуваного розчину 3 метою вивчення якісного складу 1,0 г здрібненого на порошок лушпиння цибулі розтирали в ступці з 10 мл етанолу протягом 5 хв, далі настоювали 20 хв, відфільтровували і наносили смугами на хроматографрічну пластинку, поряд наносили стандартні зразки антоціанів, висушували на повітрі та хроматографували в системі розчинників етилацетат - оцтова кислота - мурашина кислота - вода (100:11:11:25). Отримані хроматограми висушували на повітрі та переглядали при денному світлі [10].

РЕЗУЛЬТАТИ Й ОБГОВОРЕННЯ. У реЗУЛЬтаті хроматограсрічного дослідження в лушпинні цибулі ріпчастої обох сортів, порівняно з достовірними зразками антоціанів, було виявлено мальвідин-3-О-глікозид, мальвідин-3,5-диглікозид, дельфінідин-3-О-глікозид, ціанідин-3-О-глікозид, ціанідин-3,5-диглікозид.

Для визначення умов, які дають змогу вилучити найбільшу кількість антоціанів, проведено ряд досліджень. Було визначено вплив концентрації кислоти хлористоводневої, а також температуру, при якій здійснювали екстракцію. Як екстрагент використано етанол різної концентрації, який містив 1 \%, 3 \%, 5 \% кислоти хлористоводневої. Екстракцію проводили при кімнатній температурі та при температурі кипіння екстрагента. Наважка сировини, ступінь ії подрібнення та час екстракції були однаковими.

Найбільший вихід антоціанів із лушпиння цибулі ріпчастої обох сортів спостерігали при використанні 70 \% етанолу, що містив $1 \%$ кислоти хлористоводневої (табл.). Спектр поглинання випробовуваного розчину лушпиння цибулі ріпчастої, який одержано при визначенні вмісту антоціанів у лушпинні цибулі ріпчастої сорту "Ред барон", наведено на рисунку.

Результати визначення суми антоціанів у лушпинні цибулі ріпчастої обох сортів були вищими при екстрагуванні за температури кипіння екстрагента, але надлишкове збільшення температури екстрагування може призвести до часткового гідролізу антоціанів та проантоціанідинів і завищення результатів визначення. Тому було вирішено проводити екстракцію за кімнатної температури і збільшити час екстракції до 1 год при періодичному перемішуванні. У результаті проведених досліджень встановлено, що лушпиння цибулі ріпчастої сорту "Ред барон" 
Таблиця - Вплив екстрагента на вихід антоціанів із лушпиння цибулі ріпчастої

\begin{tabular}{|l|c|c|c|c|c|}
\hline \multirow{2}{*}{\multicolumn{1}{|c|}{ Назва сировини }} & \multicolumn{5}{|c|}{ Вміст антоціанів, \% } \\
\cline { 2 - 6 } & $\begin{array}{c}40 \% \text { етанол, } \\
1 \% \mathrm{HCl}\end{array}$ & $\begin{array}{c}50 \text { \% етанол, } \\
1 \% \mathrm{HCl}\end{array}$ & $\begin{array}{c}70 \text { етанол, } \\
1 \% \mathrm{HCl}\end{array}$ & $\begin{array}{c}80 \% \text { етанол, } \\
1 \% \mathrm{HCl}\end{array}$ & $\begin{array}{c}96 \% \text { етанол, } \\
1 \% \mathrm{HCl}\end{array}$ \\
\hline $\begin{array}{l}\text { Лушпиння цибулі ріпчастої } \\
\text { сорту “Ред барон" }\end{array}$ & 0,090 & 0,094 & 0,097 & 0,095 & 0,095 \\
\hline $\begin{array}{l}\text { Лушпиння цибулі ріпчастої } \\
\text { сорту “Марс" }\end{array}$ & 0,290 & 0,298 & 0,320 & 0,315 & 0,310 \\
\hline
\end{tabular}

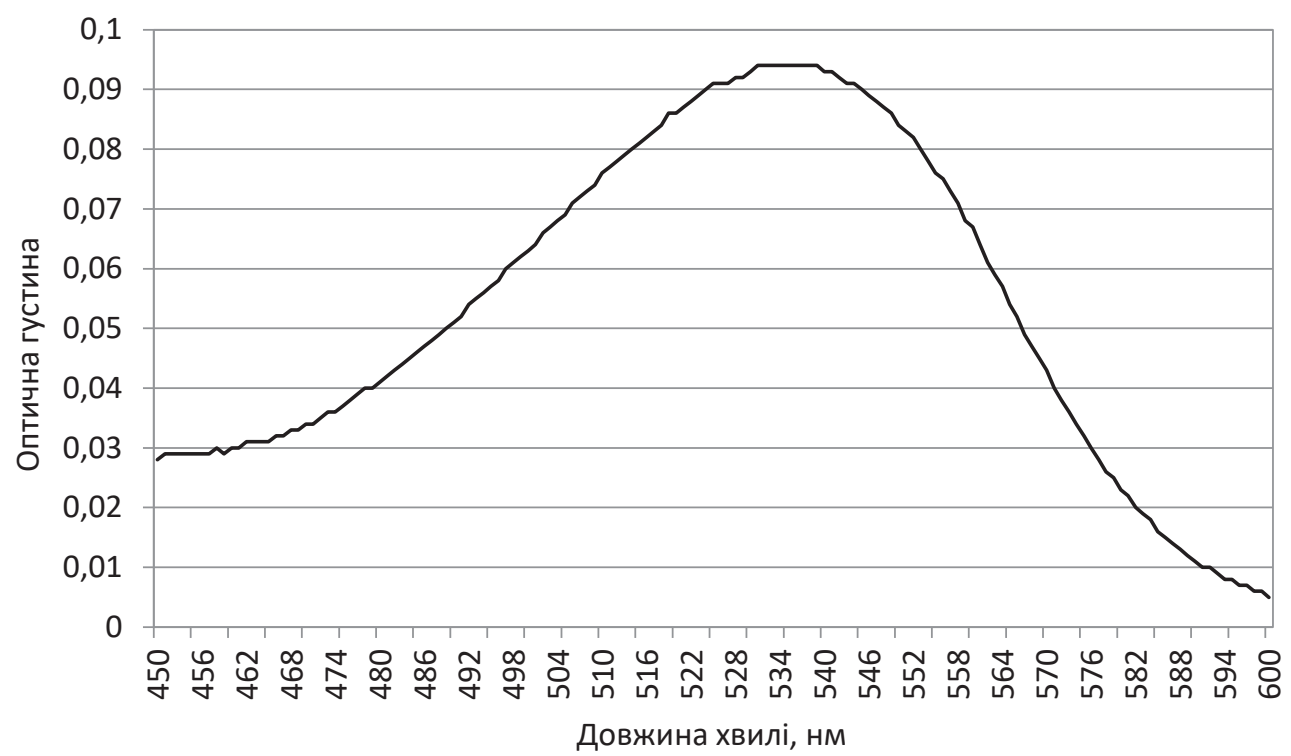

Рис. Спектр поглинання випробовуваного розчину лушпиння цибулі ріпчастої, який одержано при визначенні вмісту антоціанів у лушпинні цибулі ріпчастої сорту "Ред барон”.

містило $97 \% \pm 0,003$ антоціанів у перерахунку на ціанідину-3-глікозид, а сорт "Марс" характеризувався вищим вмістом антоціанів, який становив $0,320 \% \pm 0,002$.

ВИСНОВКИ. 1. Методом тонкошарової хроматограсрії, порівняно з достовірними зразками, в лушпинні цибулі ріпчастої сортів "Ред барон"

\section{СПИСОК ЛІТЕРАТУРИ}

1. Михайлов А. В. Образование и переработка отходов пищевой промышленности в Алтайском крае / А. В. Михайлов, Н. Я. Тейхреб // Ползуновский вестн. 2015. - № 2. - C. 59-63.

2. Консультативные программы IFC в Европе и Центральной Азии. Обращение с отходами агропромышленного комплекса: возможности для Украины. K., 2013. -28 c.

3. Jurgiel-Malecka G.Comparison of chemical composition of selected cultivars of white, yellow and red onions / G. Jurgiel-Malecka, M. Gibczynska, M. Nawrocka-pezik / Bulgarian Journal of Agricultural Science. 2015. - 21 (4). - P. 736-741. та "Марс" ідентифріковано 5 антоціанових глікозидів.

2. Проведені дослідження дали змогу підібрати оптимальні умови для максимального вилучення антоціанів із лушпиння цибулі ріпчастої з метою визначення їх кількісного вмісту.

3. Визначено кількісний вміст антоціанів у лушпинні цибулі ріпчастої сортів "Ред барон" та "Марс".

4. Characterization of domestic onion wastes and bulb (Allium cepa L.): fatty acids and metal contents / M. O. Bello, I. O. Olabanji, M. Abdul-Hammed, T. D. Okunade // International Food Research Journal. - 2013. 20 (5). - P. 2153-2158.

5. Державний реєстр лікарських засобів України [Електронний ресурс]. - Режим доступу : http://www. drlz.com.ua.

6. Anthocyanins in medicine / Edward Kowalczyk, Pawe Krzesiñski, Marcin Kura [et al.] // Polish Journal of Pharmacology. - 2003. - 55 (5). - P. 699-702.

7. Рязанова Т. К. Фармакогностическое исследование плодов и побегов черники обыкновенной / 
Т. К. Рязанова // Фундаментальные исследования. 2013. - № 8. - C. 1136-1140.

8. Analysis and characterisation of anthocyanins in mulberry fruit / Chuanguang Qin, Yang Li, Weining Niu [et al.] // Czech J. Food Sci. - 2010. - 28, No. 2. P. 117-126.

9. Державна Фармакопея України : в 3 т. / Державне підприємство "Український науковий фрармакопейний центр якості лікарських засобів". - 2-ге вид. -
Харків : Державне підприємство "Український науковий фрармакопейний центр якості лікарських засобів", 2014. - T. 2. - 724 c.

10. Assessment of the anthocyanidin content of common fruits and development of a test diet rich in a range of anthocyanins / Giulia Coronaa, Fiona Tanga, David Vauzoura [et al.] // Journal of Berry Research. 2011. - No. 1. - P. 209-216.

\section{REFERENCES}

1. Mikhaylov, A.V., \& Teykhreb, N.Ya. (2015). Obrazovaniye i pererabotka otkhodov pishchevoy promyshlennosti $v$ Altayskom kraye [The formation and processing of food industry waste in the Altai Territory]. Polzunovskiy vestnik - Polzunovskiy Journal, 2, 59-63 [in Russian].

2. Konsultativnyye programmy IFC v Evrope i Tsentralnoy Azii. Obrashcheniye s otkhodami agropromyshlennogo kompleksa: vozmozhnosti dlya Ukrainy [IFC Advisory Programs in Europe and Central Asia. Management of agricultural waste: opportunities for Ukraine]. Kiev [in Russian].

3. Jurgiel-Malecka, G., Gibczynska, M., \& NawrockaPezik, M. (2015). Comparison of chemical composition of selected cultivars of white, yellow and red onions. Bulgarian Journal of Agricultural Science, 21 (4), 736-741.

4. Bello, M.O., Olabanji, I.O., Abdul-Hammed, M., \& Okunade, T.D. (2013). Characterization of domestic onion wastes and bulb (Allium cepa L.): fatty acids and metal contents. International Food Research Journal, 20 (5), 2153-2158.

5. Derzhavnyi reiestr likarskykh zasobiv Ukrainy. Elektronnyi resurs [State Register of Medicinal Products of Ukraine. Electronic resource]. Retrieved from: http:// www.drlz.com.ua

6. Edward Kowalczyk, Pawe Krzesiñski, Marcin Kura, Bartosz Szmigiel, \& Jan Baszczyk (2003). Anthocyanins in medicine. Polish Journal of Pharmacology, 55 (5), 699-702.

7. Ryazanova, T.K. (2013). Farmakognosticheskoye issledovaniye plodov i pobegov cherniki obyknovennoy [Pharmacological study of fruit and blueberries common roots]. Fundamentalnyye issledovaniya - Fundamental Researches, 8, 1136-1140 [in Russian].

8. Chuanguang Qin, Yang Li, Weining Niu, Yan Ding, Ruijie Zhang \& Xiaoya Shang (2010). Analysis and characterisation of anthocyanins in mulberry fruit, Czech J. Food Sci., 28, 117-126.

9. (2015). Derzhavna Farmakopeia Ukrainy: v 3 t. / DP "Ukrainskyi naukovyi farmakopeinyi tsentr yakosti likarskykh zasobiv". 2-e vyd. [State Pharmacopoeia of Ukraine: 3 tons / State Enterprise "Ukrainian Scientific Pharmacopoeia Center for the Quality of Medicines". - 2nd edition]. Kharkiv: DP "Ukrainskyi naukovyi farmakopeinyi tsentr yakosti likarskykh zasobiv" [in Ukrainian].

10. Giulia Coronaa, Fiona Tanga, David Vauzoura, Ana Rodriguez-Mateosa, \& Jeremy P.E. Spencera (2011). Assessment of the anthocyanidin content of common fruits and development of a test diet rich in a range of anthocyanins. Journal of Berry Research, 1, 209-216.

\section{ИССЛЕДОВАНИЕ АНТОЦИАНОВ ШЕЛУХИ ЛУКА РЕПЧАТОГО}

\section{Резюме}

Вступление. Актуальной задачей современности является изучение химического состава и биологической активности отходов растениеводства. К растениям, которые образуют как первичные, так и вторичные отходы, относится лук репчатый - Allium сера L., семейства Alliaceae. Первичные отходы лука репчатого (шелуха) образуются непосредственно после сбора урожая, вторичные - при переработке пищевой промышленностью (ГСТУ-3234-95 - Лук репчатый свежий). 
Цель исследования - изучить качественный состав и количественное содержание антоцианов в шелухе лука репчатого сортов "Ред барон" и "Марс".

Методы исследования. Наличие данной группы соединений в шелухе лука репчатого обоих сортов подтверждали качественными реакциями со щелочью и свинцом ацетатом основным и тонкослойной хроматографией. Для количественного определения суммы антоцианов использовали модифицированный спектрофротометрический метод, приведенный во 2-м издании Государственной Фармакопеи Украины, в частности в монографрии “Черники плоды свежие".

Результаты и обсуждение. В результате хроматографрического исследования в шелухе лука репчатого обоих сортов, в сравнении с достоверными образцами антоцианов, было обнаружено мальвидин-3-О-гликозид, мальвидин-3,5-дигликозид, дельфинидин-3-О-гликозид, цианидин-3-О-гликозид, цианидин-3,5-дигликозид. Методом прямой спектрофотометрии в шелухе лука репчатого сортов "Ред барон" и "Марс" установлено количественное содержание антоцианов - 0,097\% \$0,003 и 0,320 \% 0,002 coomветственно.

Выводы. Методом тонкослойной хроматографии, в сравнении с достоверными образцами, в шелухе лука репчатого сортов "Ред барон" и “Марс" идентифицировано 5 антоциановых гликозидов. Подобрано оптимальные условия для максимального извлечения антоцианов из шелухи лука репчатого. Определено количественное содержание антоцианов в шелухе лука репчатого сортов "Ред барон" и "Марс".

КЛЮЧЕВЫЕ СЛОВА: антоцианы; лук репчатый; шелуха.

V. Yu. Kuznetsova ${ }^{1}$, V. S. Kyslychenko ${ }^{1}$, N. A. Sushchuk ${ }^{2}$ NATIONAL UNIVERSITY OF PHARMACY' ODESA NATIONAL MEDICAL UNIVERSITY²

\title{
ONION'S PEELS ANTHOCYANINS STUDYING
}

\begin{abstract}
Summary
Introduction. The studying of the chemical composition and biological activity of plant wastes is an actual problem. The Onion - Allium cepa L., the family Alliaceae belong to the plants that form both primary and secondary wastes. Primary wastes of onion - peels, are formed immediately after harvesting. Secondary are formed during processing of food industry.

The aim of the study - to learn the qualitative composition and quantitative content of anthocyanins of Onion's peels of the "Red Baron" and "Mars" varieties.

Research Methods. The presence of this group of compounds in the onion peels of both varieties was confirmed by qualitative reactions with alkali and lead acetate and thin-layer chromatography. The modified spectrophotometric method according to State Pharmacopoeia of Ukraine 2 edition monograph "Blueberry fresh fruits" was used for quantitative determination of anthocyanins.

Results and Discussion. Malvidin-3-O-glycoside, malvidin-3.5-diglycoside, delphinidin-3-O-glycoside, cyanidin3-O-glycoside, cyanidine-3.5-diglycoside were identified in onion's peels both varieties. The content of anthocyaninsin Onion's peels of the "Red Baron" and "Mars" varieties was determined by spectrophotometric method.

Conclusions. 5 anthocyanin glycosides were identified in Onion's peels "Red Baron" and "Mars" varieties using thin layer chromatography. Optimal conditions to maximize the extraction of anthocyans from the Onion peels were selected. The quantitative content of anthocyanins in the Onion peels of the "Red Baron" and "Mars" varieties was determined.
\end{abstract}

KEY WORDS: anthocyanins; onion; peels.

Адреса для листування: В. Ю. Кузнєцова, Національний фрармацевтичний університет, вул. Валентинівська, 4, Харків, 61168, Україна, е-mail: kuznetsova.victoria@ukr.net. 